\title{
THE INFLUENCE OF PLANNING DECISIONS REGARDING LAND EVALUATION BASED ON A SELECTED LOCAL REAL ESTATE MARKET
}

Iwona Foryś, assoc. prof., PhD.

Department of Econometrics and Statistics

University of Szczecin

e-mail:forys@wneiz.pl

Ewa Putek-Szeląg, PhD.

Department of Econometrics and Statistics

University of Szczecin

e-mail:wicheru@wneiz.pl

\begin{abstract}
The article analyzes the influence of planning decisions on changes taking place on the local real estate market. Three stages of the planning process are studied in particular, i.e.: the passing of the study of conditions and directions of spatial development, the Commune Council Resolution on initiating the formulation of a local spatial development plan, and finally the Resolution on accepting the local plan, as well as the effects of these activities on the land value in a given real estate market in Stargard Szczeciński, in the West-Pomeranian (Zachodniopomorskie) Province of Poland. The object of the research is to identify the indicated relationships on a given real estate market, on which respective spatial planning stages can be distinguished, as well as the strength and course of the analyzed relationships. The study will verify the research hypothesis regarding the strength and directions of the effects of planning decisions as the direct and indirect reasons behind price changes on the real estate market. The analysis uses data from the Price Register and the District Starosty Values, along with statistical and public information data and the authors' own studies.
\end{abstract}

Key words: real estate market, spatial planning, property value.

JEL Classification: R52, R58, R140

Citation: Foryś I., Putek-Szeląg E., 2015, Influence of the Planning Decisions on Land Evaluation on the Basis of The Selected Local Real Estate Market, Real Estate Management and Valuation, Vol. 23, No. 4, pp. $62-73$.

DOI: $10.1515 /$ remav-2015-0037

\section{Introduction}

Continuous development and civilizational changes, followed by the growing need for places adapted to realizing changing needs, are the reason for the transformations of physical space, where both individual entities and entire societies function. Space, through its diversity and internal features, holds different values for individual users. Its features and environment influence the attractiveness of settling there. On the other hand, man attempts to shape space according to his expectations and needs, and in his pursuit to fulfill these goals, triggers spatial processes creating various spatial structures (FORYŚ, NOWAK 2014, pp. 13-15). Some elements of spatial structures are created as a result of natural, long-lasting social-economic phenomena which are not superiorly coordinated. However, not all human activities that are individual or independent of one another lead to disorderly space. Some regularities, such as self-occurring process of spatial concentration, which involves the 
idiopathic attraction of some functions and spatial structures, can be observed; processes of urban development and suburban development or gentrification serve as examples of this (FORYŚ 2014, pp. 5-13). In contrast, we can talk about processes of organizing, using and cultivating space which are shaped by purposeful, coordinated and planned human activities. In effect, they lead to the maintenance of planned spatial order, that is to say spatial development and, in particular, spatial management (CYMERMANN 2012; KARWIŃSKA 2008). Spatial management comprises planning and decision-making, organizing, leadership and supervision directed at spatial resources. When carried out efficiently and effectively, taking into consideration the common good, it allows for spatial order to be preserved while maintaining sustainable development (FORYŚ, NOWAK 2014, p.18). In the Polish legal system, specific institutions manage space on particular administrative levels. Their powers and range of duties are defined by the Spatial Planning and Management Act of 27 March 2003 (Dz.U. of 2012, item 647). These institutions possess vital instruments of spatial policy, such as the study of conditions and directions of spatial development, local spatial development plan, or decisions regarding the building conditions and the development of land, which facilitate effective spatial management in accordance with social norms. The aim of this article is to identify the relationships on the Stargard Szczecinski real estate market based on which it is possible to select possible spatial land use stages, and the strength and direction of the analyzed relationships. The article reviews the classical analysis of time series estimating the parameters of activity of the trend line for District 16, and separately for the entire town, followed by the hypothesis of parameter equality with the time variable. The analysis uses Price Register and the District Starosty Value data along with statistical and public information data, and data from the authors' own studies.

\section{The spatial policy system}

\subsection{Spatial planning system}

The spatial planning system supports the development strategy accepted by society. Taking into consideration the fact that spatial resources are non-renewable, the role of the system is to support the established directions of development in congruence with the parameters of the political, social and economic system of a given region.

The above-mentioned system includes the normalization of spatial processes, planning at the operational level, inspections encompassing administrative and institutional supervision, as well as the execution of the assumed principles. The first element of the system focuses on formulating the general recommendations regarding and the directions of spatial development. Legal acts, directives or strategic documents of a general nature are issued. The planning subsystem is of an operational nature, involving the development of scenarios and a vision of the future state of space, that is the building of prognoses. Formalizing and elaborating on the most probable scenario constitutes the programming stage, which can be identified with the assumptions of the directions of development and spatial management. The third element is elaborating on the proposed solutions and preparing them in a graphic or descriptive form, as laid out by the given planning system. This is the stage of preparing spatial development plans for given areas.

The spatial planning phase comprises three levels: commune (gmina), provincial (województwo), and domestic. The following documents are prepared as a result:

- commune level - the study of the conditions and directions of spatial development of the commune and local spatial development plans of the commune,

- provincial level - provincial spatial development plan,

- domestic level - the concept of the spatial development of the country.

The concept of domestic land use is a document by means of which the spatial policy of the country is established. The concept is cohesive with the aims included in the government strategic documents, and takes into consideration the principles of the sustainable development of the country based on natural, cultural, social, and economic conditions (Art. 46, item 1 of the Act on spatial planning and development). The spatial development concept of a country is drawn up by the proper minister, responsible for issues of regional development. The spatial development plan defines the determinants, principles and directions of the formation of provincial spatial structure so that it generates conditions that are favorable to economic development, improving the standard and quality of life, and the competitiveness of the region according to the principles of sustainable development. This act interrelates the provincial authorities along with other entities in the process of implementing 
spatial policy, but as it is not an act of local law, thus it cannot constitute the basis for issuing any administrative decisions. The provincial spatial development plan defines the framework within which a commune draws up a study of conditions and directions of spatial development. The local spatial development plan of a commune is in fact an act of local law.

The subsystem of enforcement comprises the control mechanisms of the individual elements of the entire system as well as each of its elements. Supervision is carried out by state-appointed and other authorized service units, inspectorates and monitoring bodies, as well as social control. Completing the above-mentioned systems of spatial planning is the subsystem of executing the assumed postulates, which is to ensure that the concepts and plans are implemented by the society.

The instruments of spatial policy are to ensure rational land use and prevent spatial conflicts. Their task is to support the maintenance of spatial order, which means such spatial development that creates a harmonious whole and takes into consideration, in well-ordered relations, all possible conditions and demands: functional, socio-economic, environmental, cultural and compositionalaesthetic. This is a state in which society functions optimally in the spatial surroundings, with the smallest possible number of conflicts. The instrument of spatial policy supporting the maintenance of spatial order is spatial planning, with the study of conditions and directions of spatial development being its direct instrument.

\subsection{Study of conditions and directions of spatial development}

The study of the conditions and directions of spatial development is a program document, obligatory for every commune. It constitutes a set of directives defining the future targets with respect to spatial order in the entire area of the commune. The role of the study is to facilitate the implementation of a coherent planning concept for the entire area of the commune, considering its real developmental and characterized by farsightedness in the adopted concepts of land use. The study is always drawn up simultaneously for the entire area of the given commune. It is not a one-off document, and can undergo changes and be updated. The study consists of a textual part, comprising two main chapters, regarding the conditions followed by the directions of spatial development, as well as a graphic section. The conditions include the characteristics of the current state of the spatial development of the commune. More specifically, this chapter comprises the following:

- the characteristics of former intended use, development and utilities,

- assessment of the spatial order and needs for its protection,

- an assessment of the state of the environment,

- an assessment of state cultural heritage,

- an assessment of the conditions and quality of life of the inhabitants,

- an assessment of the needs and possibilities for the development of the commune,

- a characterization of the legal status of the land,

- detailed information concerning, among others, tasks which are to serve the purpose of implementing regional public aims.

The directions are the second, textual part of the planning studies. They contain the most important guidelines and assumptions concerning the spatial development of the commune, in particular pertaining to:

- the changes in the spatial structure of the commune and intended land use,

- the development and use of land, especially that excluded from building,

- protection of the environment and cultural heritage,

- the transportation system and technical infrastructure,

- mineral deposits.

The study also indicates the problem areas strategic for the commune or country, and connected with energy safety, national defense, or others differing from typical intended use or means of establishing local plans.

The procedure of preparing the study of conditions and directions of spatial development comprises several stages:

- a public announcement on the commencement of works on the passing or change of the study,

- preparing a project of the study,

- agreeing on the project of the study in terms of congruence with the provincial spatial development plan and other government programs, 
- expressing an opinion regarding the project by proper bodies and institutions, for example: the District Starosty, governing bodies of neighboring communes, the provincial conservator of monuments, etc.,

- social consultations connected with the project of the study,

- the passing of the planning studies by the Commune Council.

The procedure of preparing and passing the study is compatible with the procedure of passing the local spatial development plan in the area of the commune.

The study of conditions and directions of spatial development is the first signal for real estate owners on the potential functions which may be created on their properties and in their neighborhood in the future. That is why the passing of the study by the Commune Council is often the first signal for real estate market participants regarding the possibilities of the development of a given area with respect to its value.

\subsection{Local spatial development plan}

As opposed to the study of conditions and directions of spatial development, the local spatial development plan is a document which does not have to refer to the entire area of a commune, as its range depends on acceptance by the Commune Council. There is also no need to draw up such a document (it is facultative, with some exceptions), and activities concerning the change of land use are assumed on the basis of decisions regarding building and development conditions. The most important feature is that it is an act of local law, binding all property owners whose properties lie within its scope.

The plan is divided into textual and graphic parts. These are more detailed than their study counterparts. The plan must comprise elements such as:

- the intended land use of the areas,

- lines dividing areas of different intended use or different development conditions,

- rules governing development and indicators of land use,

- limitations of land use and development,

- principles of protecting and shaping spatial order, environmental protection and the protection of cultural heritage and monuments,

- requirements resulting from the needs of shaping public space,

- borders or ways of developing protected areas and buildings,

- rules and terms of merging and dividing real estate covered by the given local plan,

- rules regarding the modernization, expansion and construction of transport systems and technical infrastructure,

- the rate of the planning fee.

In the context of further considerations concerning the changes in land value together with the progressive planning process, particular attention is to be paid to the effects of the individual changes, which are introduced by the newly passed local spatial development plan. The effects can be positive for owners of land covered by the plan when the new regulations extend the owners' rights, for example in regards to rules governing development or land use indicators. On the other hand, the records of the new plan may bring the opposite results for an owner when the elements of the local plan limit the rights of landowners whose property falls within the areas covered by the plan. For example, such a legal limitation may concern prohibiting development or very restrictive rules regarding development.

The local plan establishes the borders of areas that require the merging and division of real estate and rehabilitation of the existing development and technical infrastructure, as well as areas in need of transformation or reclamation, and the borders of the distribution of areas for public investments. The means of situating land with reference to roads and other publicly accessible areas, and borders of adjacent properties, are also defined, as well as the color scheme of buildings and roof covers, rules regarding the location of elements of garden architecture, signs, advertisement fixtures and the minimal surface area of the newly demarcated building plots. The specificity of the plans results from local needs, however the local land use plan cannot contravene the arrangements of the study of conditions and directions of spatial development. The procedure for formulating the local spatial development plan includes:

- passing a resolution by the Commune Council concerning the commencement of the 
preparation of a local plan (the passing of the resolution can be initiated by anybody: be it an executive commune body, a group of councilmen, or even a group of the interested citizens),

- the head of the commune (wójt) or mayor announces the passing of a resolution concerning the commencement of the formulation of a local plan and the time-scale (no shorter than 21 days, commencing from the day of the announcement) for bringing forward motions concerning the plan,

- works on the project of the plan, assessed by the architectural and urban planning committees of the commune,

- agreement and evaluation procedures by proper administrative organs and state institutions

- social consultations regarding the project of the plan which finalize the changes introduced to the plan resulting from the written remarks and complaints,

- handing over the draft of the plan to the Commune Council, which then confirms that the plan does not contravene the decisions of the planning studies and decides on the means of looking into the remarks and complaints regarding the plan;

- the resolution of the Commune Council adopting the local spatial development plan,

- submitting the resolution along with attachments to the Province Governor, who assesses its congruence with legal regulations,

- the resolution comes into force, no earlier than 14 days following its publication in the official provincial register.

The local plan can influence the value of property covered by it in different ways; in particular, it can lead to an increase or decrease of its value. In the Act on spatial planning and development, a decrease in property value is associated with cases when, in connection with the enactment of the local plan or its change, the former use of the property (or part of it) has become impossible or severely limited. In such a case, the property owner or its perpetual lessee can claim compensation from the commune, in the form of damages for the losses suffered or replacing the property or its part with a different one. In the event of an increase in property value resulting from the changes in the plan, the financial effects (planning fee) occur in when the owner or perpetual lessee has sells an affected property within 5 years from the date of the local plan coming into force. The maximum fee is $30 \%$ of the increase in property value. Such a fee is an obligatory element of each local plan. The lack of it can cause the local plan to be considered invalid.

\section{Change of property value in the planning process on the example of a selected area of Stargard Szczeciński Commune}

\subsection{Property value in the context of spatial planning}

In the process of spatial management, the problem of valuating land is of increasing importance. It often exhibits a purely economic dimension associated with land value as an effect of its utility, rarity and marketability. It is also the value in use connected with the usefulness for serving a particular function, most often resulting from the natural values of the land (landform, soil-water conditions and climate, mineral resources, etc.) and ecological values of the environment, as well as being the effect of human activity (development, infrastructure) or cultural heritage (CYMERMAN 2012). In a market economy, land value may be identified with its market value, as it may constitute the subject of market turnover (for example, land for development) or its worth, which does not always assume a financial dimension (ecological preciousness) but plays an important role in the hierarchy of social values. That is why contemporary spatial management is an activity which adapts geographic space to human needs and values according to the rules of sustainable development. Moreover, the rule of location coherence is a foundation of rational spatial policy (GORZYM-WILKOWSKI 2006). It concerns the pursuit of a prime location for each activity in space, which means such a place that is characterized by the best features for its anticipated function. This means that, for every location in space with defined feature, the proper functions should be chosen. However, this is not always in agreement with the individual expectations of the users of the space, in particular property owners whose properties lose value as a result of planning decisions (KAZAK, SASIK, SZEWRAŃSKI 2013).

Planning decisions determine the use of undeveloped land, at the same time influencing its market value. Both location theory and scientific research presented in global and domestic literature (KRAJEWSKA, ŹRÓBEK, ŚUBIC KOVAĆ 2014; FRIEDMAN 2004) indicate a strong dependency of planning decisions on land use, as well as on the worth of land property. The strength of these relationships 
and their direction vary in time; they also have local importance. The effects of planning decisions are also shifted in time.

The increase in property value as an effect of planning changes is usually the highest when it concerns the transformation of an agricultural function into residential, industrial or service functions (A-B). Another substantial increase in property value occurs in the process of property division (B-C). The following stage of value growth takes place when a property gains access to technical infrastructure (C-D). Finally, the last element causing an increase in value is exclusion from agricultural production (D-E). Further increases in value are the result of building up the land property, thus proper investments (E-F). The process is described in the figure below (Figure 1).

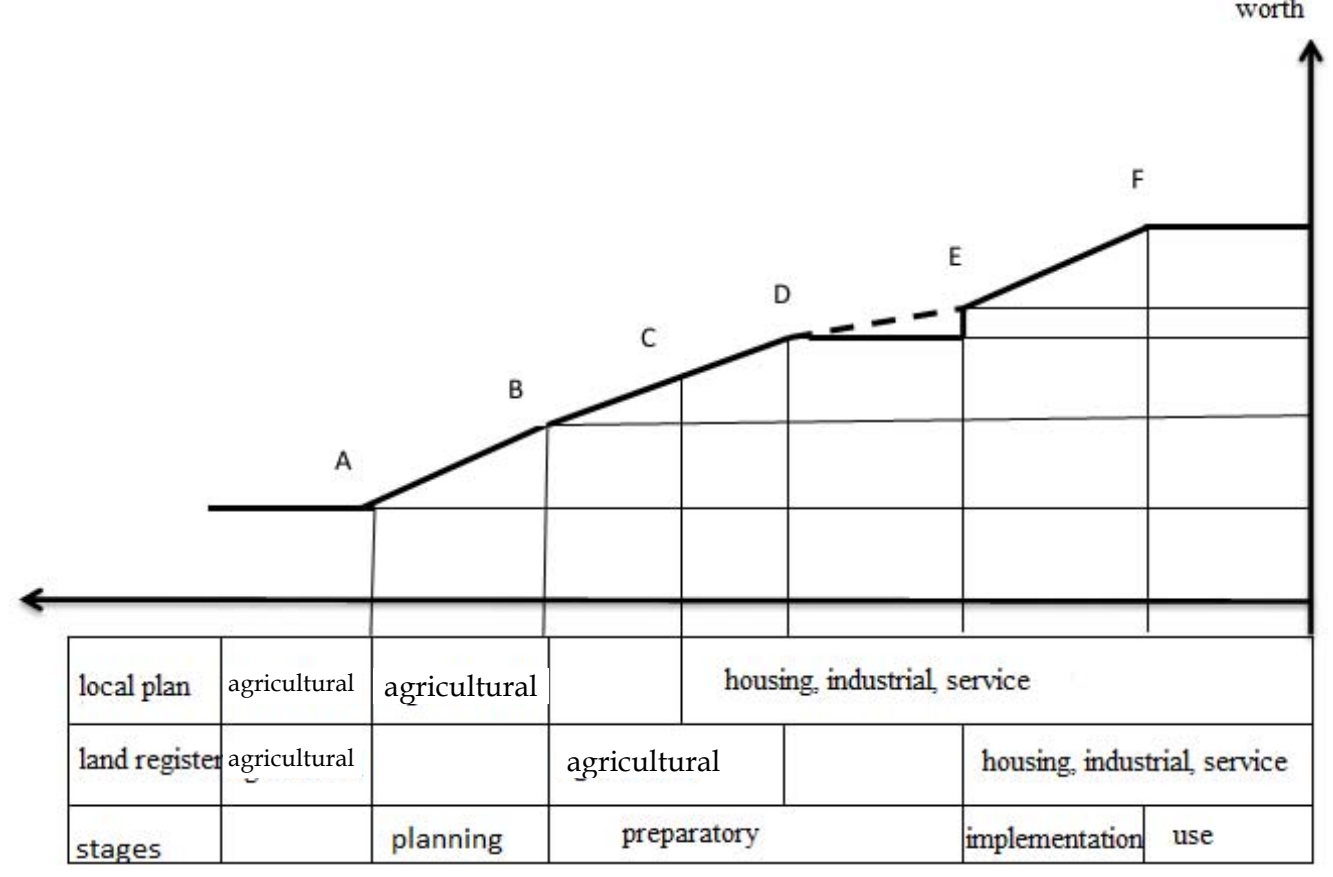

Fig. 1. The change of property value in the investment process. Source: own elaboration based on (CymermanN, Telega 2006, p. 12).

The highest increases in value pertain to, above all, non-urbanized land. The adoption of the planning studies increases the probability of a given area of land to have developmental potential, thus its value will increase. In practice, it is most difficult to determine the influence of the passing of a study of conditions and directions of spatial development on the increase in property value. The scope and the strength of such influence depends on the proposed usage (the more detailed the description, the easier it is to establish such an influence) and clarity of records (ambiguous records concerning use decrease the probability of predicting the future function in the plan).

The highest increase in property value in the case of favorable planning changes, involving an increase in the market potential of real estate, occurs when specific planning activities are assumed, that is upon adopting a resolution concerning the commencement of works on a local spatial development plan, which further results in a resolution accepting the project of the plan. The effects of planning changes are also experienced by neighboring properties.

The commencement of the procedure for passing the local spatial development plan usually results in evident changes in the property prices of undeveloped, or developed land that anticipates a more valuable function for the market. The intensity and pace of changes in the market prices of these properties are also conditioned not only by the demand for them on the given market, but also by the macroeconomic surroundings of the local real estate market. They can influence both the weakening of the dynamics of price increase, as well as the shifting of this process in time.

In order to test the influence of planning decisions on the value of undeveloped land, an experimental area for which transaction prices were available over the period of planning changes was chosen. Such a condition was met by District No. 16 of Stargard Szczeciński, located in the southern part of the town, with borders marked by Spółdzielcza, Niepodległości and Władysława Broniewskiego streets. Information concerning transactions involving undeveloped land concluded in 
the period between 2000 and 2014 for the indicated area was collected from the Price and Value Register of the District Starosty in Stargard Szczeciński. In order to compare the tendencies in price changes in the analyzed area with the tendencies for the entire city, information regarding transactions involving undeveloped land in other parts of the city was also gathered.

For the researched area, "The planning study of the conditions and directions of spatial development for the city of Stargard Szczeciński" was enacted on 26 November 2000 by Resolution No. XXVII/263/2000 of the City Council in Stargard Szczeciński. This document, predicted mainly residential functions for District No. 16: M1, M2 single-family and multi-family housing of average and low density, accompanied by services of general interest and places of work that do not cause a nuisance (Fig. 2 ).

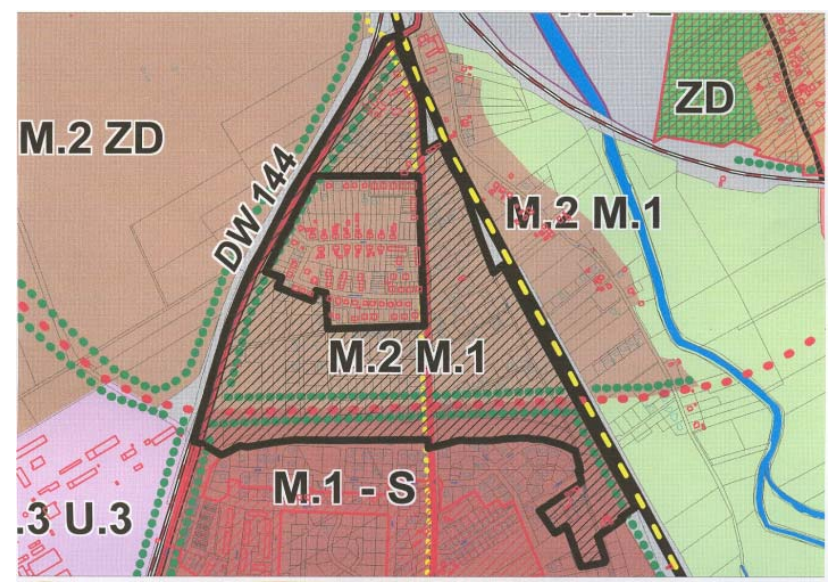

Fig. 2. An attachment to the planning study of the conditions and directions of land use of Stargard Szczeciński for District No. 16. Source: Resolution No. XXVII/263/2000 of the City Council in Stargard Szczeciński.

On 26 October 2004, Resolution No. XLVII/262/2004 of the City Council in Stargard Szczciński was passed concerning the commencement of works on the local spatial development plan for Stargard Szczeciński covering the area in the neighborhood of Spółdzielcza, Niepodległości and Władysława Broniewskiego streets. The following categories of the land use were established for the area included in the plan, defined in the resolutions for elementary areas:

1. MM - solely residential areas,

2. OM - non-specialized residential areas,

3. PM - suburban residential areas,

4. OG - areas for common needs,

5. PS - production-warehouse areas,

6. TO - open areas;

7. KD - road communication areas.

On the map below (Fig. 3), which constitutes a graphic attachment to the mentioned resolution, the areas of use other than residential have been marked in red, with the area not covered by the resolution shown in light purple. For the land properties, the planning fee is $0 \%$, whereas for the remaining properties, a maximum fee of $30 \%$ was accepted.

Finally, a number of significant dates can be indicated in the discussed planning process:

- 26 October 2000 - the passing of the study of the conditions and directions of spatial development for the City of Stargard Szczeciński,

- 26 October 2004 - resolution concerning the commencement of works on the local spatial development plan for the discussed area,

- 11-25 July 2006 - publicizing the plan for the submission of remarks and complaints,

- 26 September 2006 - resolution concerning the passing of the local spatial development plan for the discussed area,

- 20 November 2006 - the publication of the resolution in the Official Register of the WestPomeranian Province No. 110, item. 2149,

- 20 December 2006 - date of the resolution coming into force. 


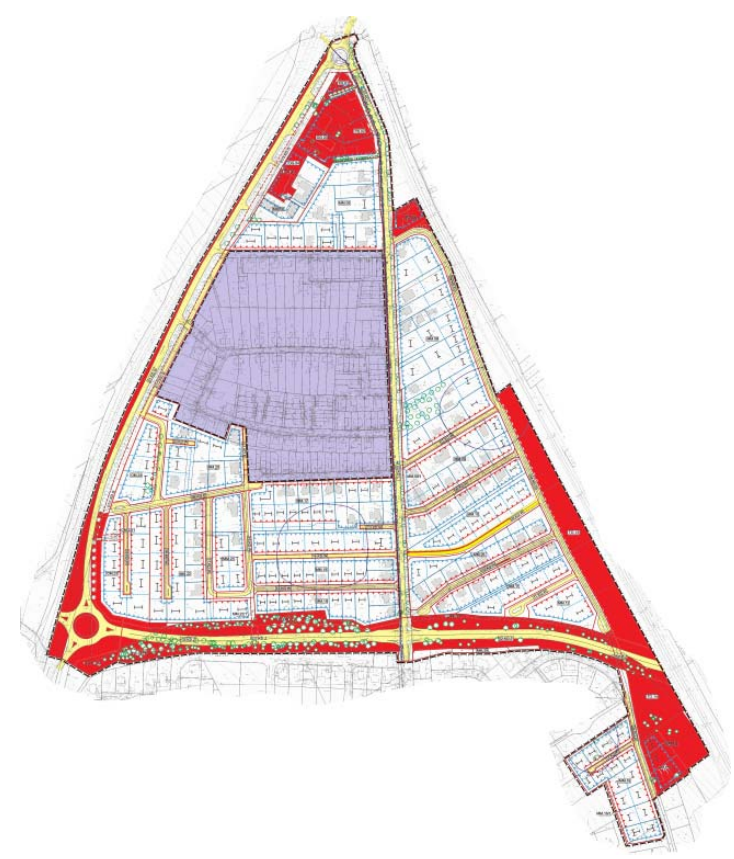

Fig. 3. Graphic enclosure to the local spatial development plan of Stargard Szczeciński concerning areas near the streets: Spółdzielcza, Niepodległości, Władysława Broniewskiego. Source: Resolution No. XLVII/504/2006 of the City Council in Stargard Szczeciński.

In order to prove the experimental hypothesis, the average transaction prices of undeveloped land were indicated in District 16 as well as the entire city, obtaining two series of average transaction prices in the years 2000-2014. The research on price changes was focused on the years 2000, 2004 and 2006, during which the significant events connected with the planning process took place. Detailed analysis of the time series indicated a lack of transactions withiin District 16 in the periods from when the individual planning decision were made in a given year to the end of the calendar year. This made it possible to indicate the average annual transaction prices for land in the discussed area.

Increases in prices were also indicated using chain indexes to show the years of the greatest changes in the unit prices of land up for sale.

Because of the functions of the researched area recorded in the study as well as in the local plan, the obtained results concern, above all, the effects of transforming the discussed agricultural land into residential areas.

\subsection{The results of the study}

The analysis of the studied area was commenced by establishing the average transaction prices for District 16 of Stargard Szczeciński, which covers the area under the influence of the planning changes contained in the indicated City Council resolutions. In the years of 2000-2009, no more than 10 transactions of undeveloped land, 6 transactions on average, were entered into in the area of District 16. In the years 2010-2014, 23 transactions of undeveloped land were, on average, concluded in this area. During this time period, land transactions in District 16 constituted $18.7 \%$ of all transactions of undeveloped land in the city. Such a substantial proportion resulted from the location of District 16 and the direction in which city's housing development was expanding. Price transaction analysis in District 16 makes it possible to note an increasing tendency in the years of 2000-2009, and the fall of prices along with fluctuations in the years 2010-2014, caused by recession on the real estate market (Fig. 4). A similar tendency took place in the entire city: a steady increase in the average prices of undeveloped land in the years 2000-2009, and price fluctuations and drops in the years 2010-2014. At the same time, lower dynamics of price changes can be observed in the city as a whole compared to the analyzed District 16 .

With respect to the aim of the research, three sub-periods of price changes should be considered in the analyzed district:

- in the years 2000-2004, when only the study was in operation, 
- in the years 2005-2006, when the study and resolution regarding the commencement of works on the local spatial development plan were in operation,

- in years of 2007-2014, when the local spatial development plan was in effect.

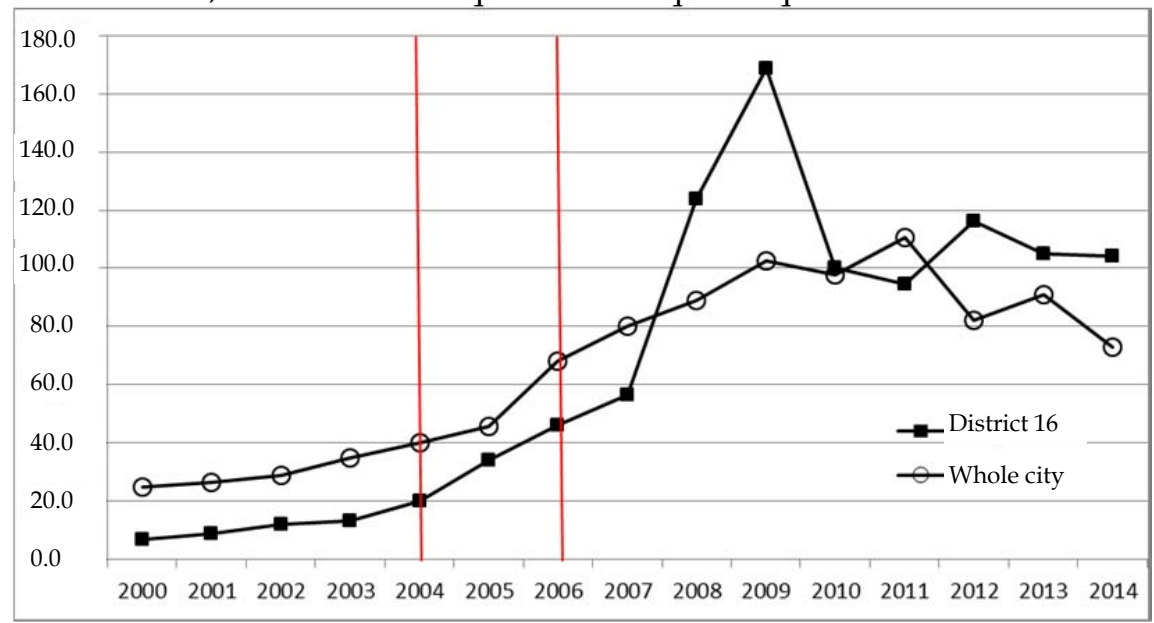

Fig. 4. The dynamics of average transaction prices of undeveloped land in Stargard Szczeciński in the years of 2000-2014 ( PLN/m²). Source: own study.

The annual increases in the average transaction prices in District 16 indicate a price increase in the years 2001-2004, following the enactment of the planning study, but a more dynamic price increase can be noticed in the years of 2004-2005, when works on the local plan were commenced (Table 1). A high increase in prices in the successive years until the year 2008 is the effect of both - the passed plan as well as the economic situation on the real estate market (the years 2006-2008). As a result of this, a drop in prices was not confirmed until 2010, prior to which the average prices of undeveloped land increased, though at varying rates. The most significant disproportion in the average prices of undeveloped land sold in the analyzed district and in the entire city was noted in 2008 and 2012, when land prices in District 16 averaged over 30PLN per square meter higher than those for the entire city. The discussed district experienced an increase in value because of further resolutions introducing local plans in the neighborhood of the district, especially connected with the localization of express road S3.

Table 1

Chain indexes of average transaction prices of undeveloped land

\begin{tabular}{cccc}
\hline Year & $\begin{array}{c}\text { District } 16 \\
(\%)\end{array}$ & $\begin{array}{c}\text { City } \\
(\%)\end{array}$ & $\begin{array}{c}\text { Difference between the } \\
\text { average price for the city } \\
\text { and District 16 (PLN/m })^{2}\end{array}$ \\
\hline 2000 & $x$ & $x$ & 18.00 \\
2001 & 29 & 6 & 17.50 \\
2002 & 34 & 9 & 16.90 \\
2003 & 9 & 21 & 21.80 \\
2004 & 52 & 14 & 20.00 \\
2005 & 71 & 15 & 11.61 \\
2006 & 35 & 49 & 21.92 \\
2007 & 22 & 18 & 23.68 \\
2008 & 119 & 11 & -34.75 \\
2009 & 36 & 15 & -66.34 \\
2010 & -41 & -5 & -2.58 \\
2011 & 6 & 13 & 16.00 \\
2012 & 23 & -26 & -34.14 \\
2013 & -9 & 11 & -14.09 \\
2014 & -1 & -20 & -30.93 \\
\hline
\end{tabular}

Source: own study. 
Next, the research focused on the years 2000-2007, which were closely connected with the planning works being carried out during this time. The passing of the planning study did not induce significant changes in the transaction prices. In the years 2000-2004, the average transaction prices in District 16 increased from 7 PLN to 20 PLN per square meter, whereas in the city - from 25 PLN to 40 PLN. The binding study and the passing of the resolution on the commencement of works on the local plan in District 16 caused an increase in the average prices, from 34.19 PLN in 2005 to 46.25 PLN in 2006 (Fig. 5).

In the same time period, i.e. 2005-2006, the average prices of undeveloped land in the entire city changed from 45.80 PLN to 68.17 PLN per square meter, respectively. In 2006 and in the successive year, a significant price increase was observed, with land prices achieving a level of almost 80 PLN per square meter (Fig. 6 ). In 2005 and in the successive years, attention should be given to the behaviors of buyers purchasing undeveloped land, connected with Poland joining the EU and the common conviction that a rapid price growth of real estate was bound to follow, Spain or Ireland serving as examples of such (TAYLOR 2011, pp. 9-15).

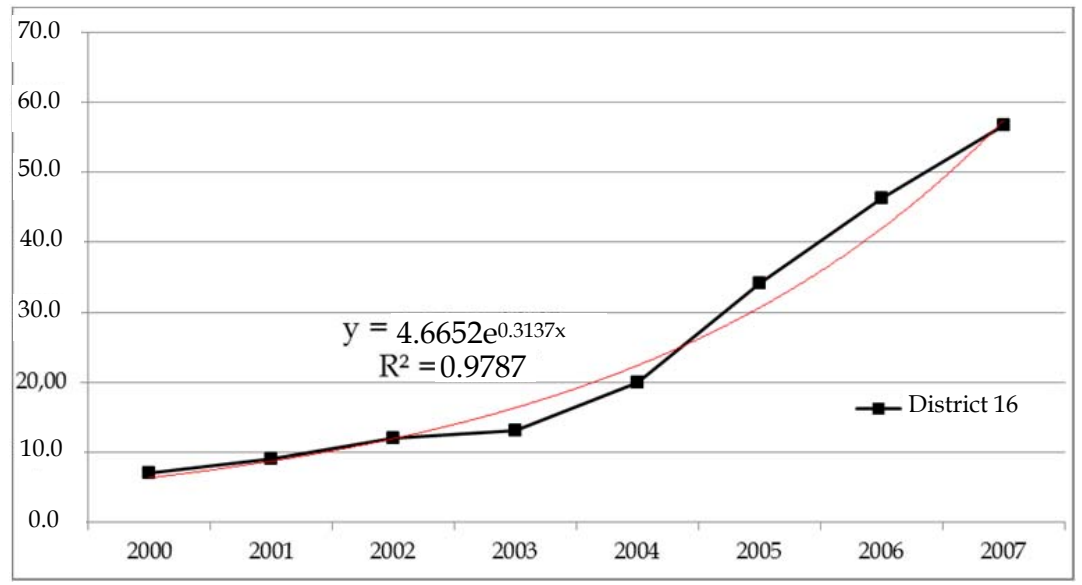

Fig. 5. Dynamics of average transaction prices of undeveloped land in District 16 of Stargard Szczeciński in the years 2007-2007 (PLN/m²). Source: own study.

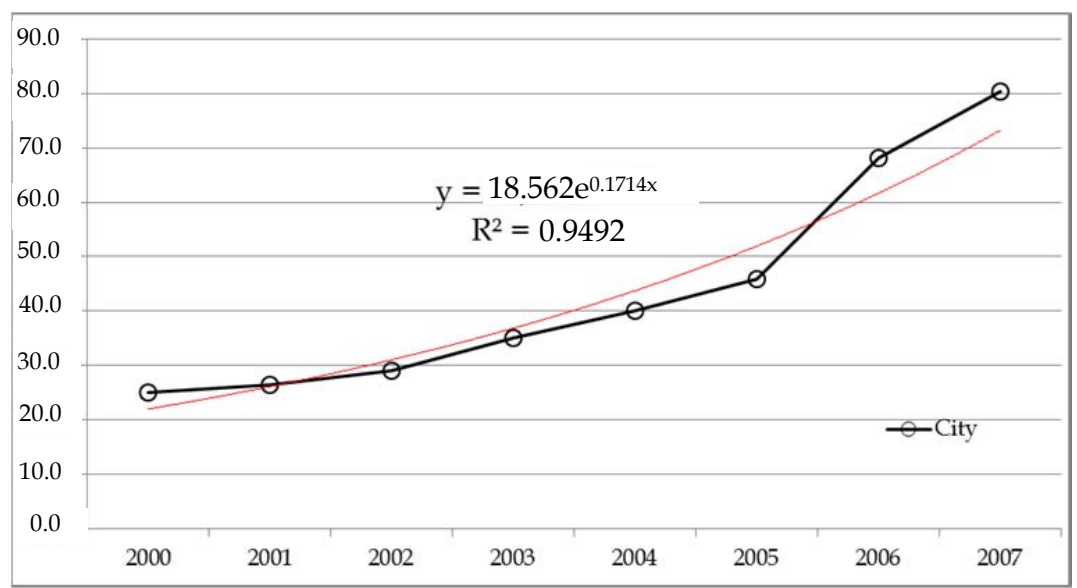

Fig. 6. Dynamics of average transaction prices of undeveloped land in Stargard Szczeciński in the years 2000-2007 (PLN/m². Source: own study.

For the researched District No. 16, as well as for the entire city, the parameters of the trend line of average transaction prices of undeveloped land were assessed. In both cases, the best match was obtained for the exponential function (Table 2 ).

In order to establish similarities in the course of the determined trends, the slope of the linear function (following linear transformation) hypothesis was tested by means of Student's t-test.

$\mathrm{H}_{0}: \mathrm{a}_{1}=\mathrm{a}_{2}$

H1: $\mathrm{a} 1 \neq \mathrm{a} 2$ 
On the basis of the obtained results, there are no grounds to reject $\mathrm{H} 0$ - that the slopes of the linear function are the same. The $\mathrm{t}$-test parameters are as follows: $\mathrm{t}=0.0147 ; \mathrm{ta}=2.201$.

Table 2

Valuation parameters of the exponential function of the trend line for average transaction prices of undeveloped land in the years of 2000-2007 in Stargard Szczeciński

\begin{tabular}{lcc}
\hline Model parameters & District 16 & City \\
\hline R2 & 0.9787 & 0.9492 \\
Standard error & 0.1226 & 0.1049 \\
& & \\
Intersection & 4.6652 & 18.5615 \\
Standard deviation & 0.0955 & 0.0818 \\
& & \\
Coefficient at variable $t$ & 0.3137 & 0.1714 \\
Standard deviation & 0.0189 & 0.0162 \\
\hline
\end{tabular}

Source: own study.

There is a strong positive dependency (Pearson's correlation coefficient equals 0.89) between the average transaction prices of the undeveloped land sold in District 16 in the years 2000-2014 and the average prices of undeveloped land sold in the entire city in the same period. This means that the price changes in a given area have the same tendency in terms of direction as in the entire city.

\section{Conclusions}

The phenomena on the real estate market are not separate from socio-economic surroundings, and that is why the valuation of the influence of planning decisions alone on the changes of prices on the real estate market is extremely difficult. Assuming the ceteris paribus law, some tendencies reflecting the behavior of the participants of the local market as a kind of reaction to the planning processes can be observed. Such tendencies concern, among others, the changes in transaction prices on the local market, and the increase in the attractiveness of areas measured by the number of transactions concluded as the planning works progress. Unfortunately, on the basis of the obtained information, it cannot be expressly confirmed that the increase in the number of transactions starting from 2009 is solely the result of planning changes, as the boom on the real estate market overlaps this period. However, the continued interest of buyers in District 16 during the period of the real estate market slump, characterized by a drop in prices resulting from the recession, can be a considered a symptom of the positive effects of the planning process carried out in this area, shifted in time. The directions of price changes in the city and in the researched district in the analyzed years are also compatible with one another. In District 16, the rate of increase is higher, especially in the years 2004-2005 and 20072009.

Follow-up research on further areas for which local spatial development plans have been passed, especially those bordering District 16, as well as more extensive cause-and-effect analysis covering other factors in the real estate market environment influencing their value can serve to complete the present analyses.

\section{References}

CYMERMAN R., TELEGA T., 2006, Rola rzeczoznawcy majątkowego przy optatach planistycznych $i$ adiacenckich (The Role of the Real Estate Appraiser regarding Planning Fees and Betterment Levies), Rzeczoznawca majątkowy (Real Estate Valuer), No. 51/2006, pp. 11-13.

CYMERMAN R., 2012, Planowanie przestrzenne dla rzeczoznawców majątkowych, zarządców oraz pośredników w obrocie nieruchomościami (Spatial Planning for Appraisers, Managers and Real Estate Agents), Educaterra, Olsztyn.

FORYŚ I., Gentrification on the Example of Suburban Parts of the Szczecin Urban Agglomeration, Real Estate Management and Valuation, Vol. 21 (2013), Issue 3, pp. 5-14.

FORYŚ I., NOWAK M., 2014, Zarządzanie przestrzenią w gospodarowaniu nieruchomościami (Space Management in Real Estate Management), Wydawnictwo Poltext, Warszawa (Poltext Publishing House, Warsaw). 
FRIEDMANN J., 2004, Strategic Spatial Planning and the Longer Range, Planning Theory \& Practice Vol. 5, Issue 1, 2004, pp. 49-67.

GORZYM-WILKOWSKI W.A., 2006, Gospodarka przestrzenna samorzadu terytorialnego (Spactial Management of Local Self-governments), Wydawnictwo Uniwersytetu Marii Curie-Skłodowskiej w Lublinie (Marie-Curie Sklodowska University Press, in Lublin).

KARWIŃSKA A., 2008, Gospodarka przestrzenna. Uwarunkowania społeczno-kulturowe (Spatial Management. Socio-Cultural Determinansts), Wydawnictwo Naukowe PWN, Warszawa (Polish Scientific Publisher PWN, Warsaw)

KAZAK J., SASIK J., SZEWRAŃSKI SZ., 2013, Gospodarowanie zasobami przestrzennymi w strefie podmiejskiej Wroctawia (Managing Spatial Resources in the Suburban Area of Wroclaw). Studia Komitetu Przestrzennego Zagospodarowania kraju PAN (Journal of the Committee for Spatial Development of the Country, Polish Academy of Sciences PAN).

KRAJEWSKA M., ŹRÓBEK S., ŠUBIC KOVAČ M., 2014, The Role of Spatial Planning in the Investment Process in Poland and Slovenia, Real Estate Management and Valuation, Vol. 22 (2014), Issue 2, pp. 52-66.

Studium uwarunkowań i kierunków zagospodarowania przestrzennego miasta Stargardu Szczecińskiego, (Study of Conditions and Directions of Spatial Development for the City of Stargard Szczecinski). Uchwała Nr XXVII/263/2000 Rady Miejskiej w Stargardzie Szczecińskim z 26 października 2000 r. (Resolution No. XXVII / 263/2000 of the City Council in Stargard Szczeciński of 26 October 2000).

TAYLOR S.F., 2011, Financial Crisis in the European Union: The Cases of Greece and Ireland, Virginia Polytechnic Institute and State University.

Ustawa z dnia 27 marca 2003 roku o planowaniu i zagospodarowaniu przestrzennym (Act of 27 March 2003 on Spatial Planning and Development). Dz. U. z 2003 r. nr 80, poz. 647 z późn. zm. (Journal of Laws, 2003, No. 80, item 647, as amended).

WIŚNIEWSKI R., 2008, Gospodarowanie gminnymi zasobami nieruchomości (Management of Municipal Real Estate Resources), Wydawnictwo Uniwersytetu Warmińsko - Mazurskiego w Olsztynie, Olsztyn. (Publishing House of the University of Warmia and Mazury in Olsztyn, Olsztyn).

Rejestr Cen i Wartości prowadzony przez Starostwo Powiatowe w Stargardzie Szczecińskim (Register of Real Estate Prices and Values kept by the Stargard Szczecinski District Office). 